\title{
THE IMPACTS OF BILATERAL TRADE AND FOREIGN DIRECT INVESTMENT ON MALAYSIA'S ECONOMIC GROWTH: THE ROLES OF SINGAPORE
}

\author{
Chee-Yie Wong \\ Universiti Tunku Abdul Rahman \\ Hui-Shan Lee* \\ Universiti Tunku Abdul Rahman \\ Shyue-Chuan Chong \\ Universiti Tunku Abdul Rahman
}

\begin{abstract}
Open economy is essential for a country to achieve sustainable economic growth. There exists a bilateral tie between Malaysia and Singapore since 1965. This relationship has made Singapore achieved as a high-income nation that enjoys modern infrastructure and technology, skilled labour, and strong financial structure, but Malaysia is still trying to upgrade itself to become a high-income nation via open economy. Furthermore, Malaysia's reliance on the external market has inevitably left the economy to be more exposed to external shock. This research analyses the impacts of Malaysia's bilateral trade and investment with Singapore on Malaysia's economic growth from 2008 to 2016. Vector error correction model (VECM) reveals that Malaysia's exports to Singapore are positive and significant on Malaysia's economic growth and Malaysia's OFDI in Singapore is significant but negative on Malaysia's economic growth. However, Malaysia's imports from Singapore and Malaysia's inward foreign direct investment (IFDI) by Singapore have insignificant impacts on Malaysia's economic growth. It concludes that only Malaysia's exports to Singapore can help to increase Malaysia's economic growth. Thus, Malaysia's government could provide incentives to encourage Malaysian local firms to boost the exportations to Singapore.
\end{abstract}

Keywords: Bilateral trade; Outward FDI; Inward FDI; Imports; Exports

Received: 5 May 2019

Accepted: 20 September 2019

\section{INTRODUCTION}

The rising of global trades and investments among the Association of Southeast Asian Nations (ASEAN) have resulted in an improvement in productivity and economic growth across ASEAN. This makes ASEAN become the third largest economy in Asia and the sixth largest economy in the world in 2016 (MITI, 2017). In the intra-ASEAN trade, Singapore has been the largest ASEAN trading and investment partner of Malaysia (Hays, 2015). The bilateral tie between Malaysia and Singapore was formed since 1965 after Singapore left the Federation of Malaysia. This has made

- Corresponding author: Universiti Tunku Abdul Rahman, Faculty of Accountancy and Management, Bandar Sungai Long, 43000 Kajang, Selangor, Malaysia. +603-90860288, hslee@utar.edu.my 
the economies of both countries highly interdependent (Kok, 2013). Furthermore, Malaysia has developed several joint venture projects with Singapore such as the establishment of rapid transit system (RTS), Marina One and Duo joint development in property and commercial market as well as the Iskandar Malaysia (Lum, 2018). The development of these various infrastructure projects and the bilateral trade and investment symbolise the close relationship between Malaysia and Singapore. This research, therefore, aims to examine the effects of Malaysia's exports to Singapore, Malaysia's imports from Singapore, Malaysia's inward foreign direct investment (IFDI) by Singapore and Malaysia outward foreign direct investment (OFDI) in Singapore on Malaysia's economic growth.

Although Malaysia has undergone a significant transformation from a predominantly agriculturebased economy to manufacturing and modern services, Malaysia is still maintaining its position as a high middle economy from 1992 until today that unable to achieve the status as a high-income county. On the other hand, Singapore is now a high-income nation as its long-term growth is driven by the availability of modern infrastructure, business-friendly macroeconomic environment, efficient labour market, strong appetite for entrepreneurship and high education level. In addition, Singapore is ranked as the third-most competitive economy in the world by the World Economic Forum (WEF) in 2016 (Lee, 2017). In order to become a high-income nation, Malaysia is now directing various economic frameworks towards innovation, knowledge and creativity via the open economy (Abidin, 2017). However, Malaysia's reliance on the external market has inevitably left the economy more exposed to external shocks. The external shocks during the period from 2008 to 2016 are the global financial crisis in 2008, depreciation in Malaysia ringgit against the Singapore dollar, the economic slowdown in the post-crisis period as well as the high competition among global players that affect Malaysia's economy. Since Singapore plays a role as the top trading and investment partner of Malaysia in ASEAN, the examinations of the relationship between (i) Malaysia's exports to Singapore, (ii) Malaysia's imports from Singapore, (iii) Malaysia's inward FDI by Singapore and (iv) Malaysia's outward FDI in Singapore on Malaysia's economic growth are important. Exploring these issues is crucial to determine whether the complementary relationship between these two countries shows a beneficial effect of trade and FDI on Malaysia's economic growth or harm to Malaysia's economic growth.

In the next section, the literature review on the previous relevant works is discussed. Section 3 discusses the data methodology, while section 4 presents the results and interpretation of data analysis. Lastly, section 5 provides overall conclusions for this research study.

\section{BACKGROUND OF THE STUDY}

In ensuring a vibrant national economic growth, the establishment of the Malaysian brand in the global market is necessary. Exports, imports, and FDI play important roles to lead the economic growth of Malaysia. Figure 1 shows the overview of exports, imports, inward FDI and outward FDI of Malaysia. As one of the fastest rising tiger cub economies in Southeast Asia, Malaysia economy is deemed as the benchmark of the substantial growth among the Southeast Asia countries. This can clearly be seen from the constant growth of Malaysia's GDP in recent years. Year 20082009 marked the fluctuating yet downward trend of Malaysia's GDP, mainly due to the global turbulence roiling the financial markets which triggered a global recession. Although not being immune to the crisis, Malaysia economy as the first in the region to respond to the crisis with 
monetary expansion had successfully cushioned the financial system against capital outflow and share market collapse. The recovery of economy from the crisis was expeditious, an upward trend in GDP growth was observed since 2009, with 2016 recorded the ceiling value of GDP growth.

Being an open economy, the outstanding performance of Malaysia economy is significantly fuelled by the export sector, especially to Singapore which accounted for more than $10 \%$ of its overall export. The strong growing export to Singapore plummeted in year 2009, then accelerated from year 2010-2016. The contraction of Malaysia export to Singapore and its overall national trade volume was triggered by an expected drop in external demand cast by global financial and economic malaise. The slowdown of E\&E export to Singapore due to the shrinking world demand, however, was perfectly offset by the growth of export of manufactured goods to Singapore, making the drop-in export temporal. Singapore continued to be Malaysia's second largest trading partner after China in recent years due to factors such as proximity, interconnectivity and complementary. The importance of the bilateral trade of Malaysia with Singapore signifies that Malaysia imports from Singapore were also noticeably large. Imports from Singapore were mainly characterized by the sectors of healthcare and wellness, green and eco-friendly, urban solution, lifestyle and convenience, professional and business support service and etc. Growth of import from Singapore is similar to that of the trend of export; a plunge in imports from Singapore was exhibited in year 2008-2009, then increased steadily over the years. This is consistent with the conventional wisdom that in an economic recession, confidence often remains low, hence consumers tend to save more and spend less. The recovery of economy fuelled market confidence, therefore consumers would increase spending and indirectly imports eventually.

The upward trend of inward FDI from Singapore to Malaysia was specifically observable in current years. Malaysia continued to be a preferred destination for Singapore firms to invest in, due to numerous policies favourable to FDI were formulated. Malaysia often being treated as a partner for Singapore firms' products and services. This is to ensure high market acceptability, competitiveness and sustainability prior to venturing into other foreign markets. An affordable labour cost and the less environmental requirement were also one of the reasons to attract inward FDI from Singapore to Malaysia.

Malaysian's outward foreign direct investment in Singapore was relatively low and consistent for many years. This indicates that the current stage of economic relations between Singapore and Malaysia was of trade partners, instead of fully economic partners. The low FDI of Malaysia in Singapore was due to the fact that Singapore prioritises investments that provides opportunities for building an ecosystem that fosters innovation and entrepreneurship through incentivizing start-ups and nurturing small medium enterprises. Due to the stringent requirement by government and limited benefits Malaysia investments can bring to the development of Singapore economy, FDI from Malaysia is considered less attractive than other foreign countries. 
Figure 1: Economic growth, exports, imports, inward FDI and outward FDI of Malaysia

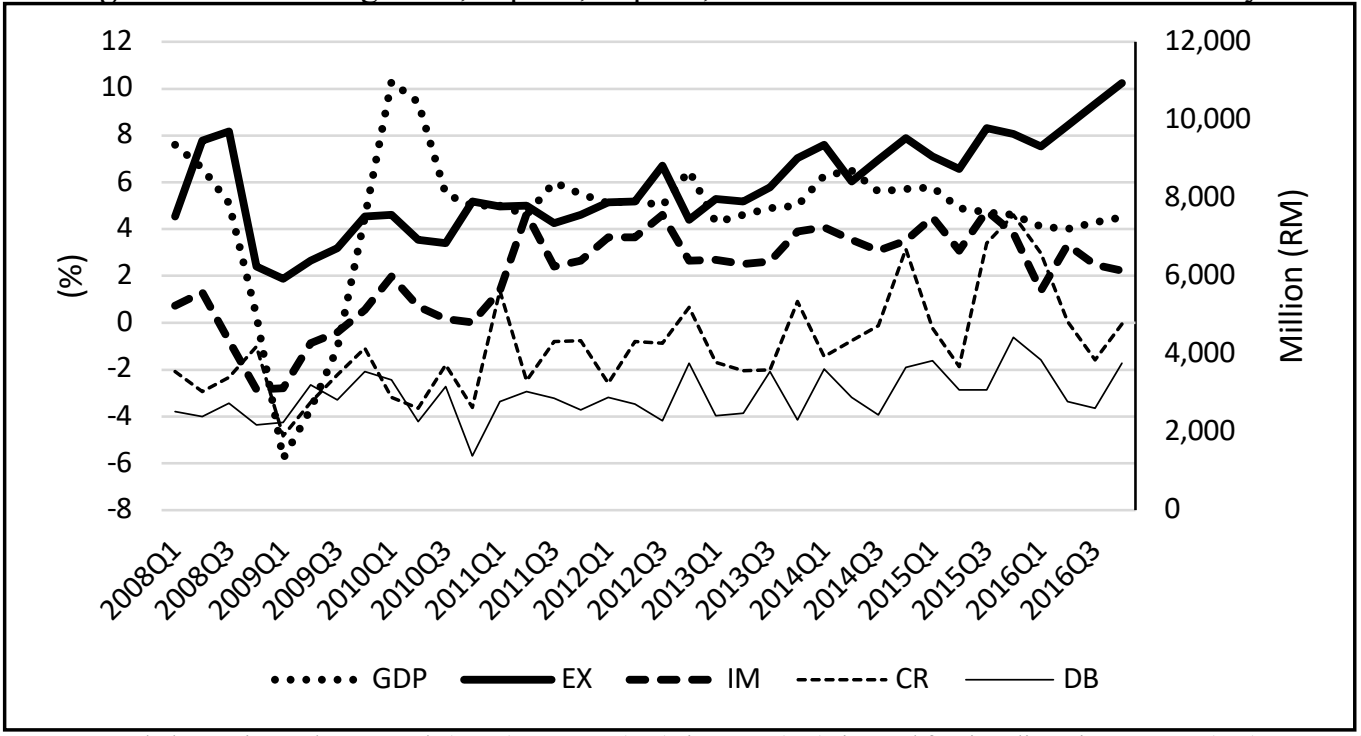

Note: Growth domestic product growth (GDP), exports (EX), imports (IM), inward foreign direct investment (CR), outward foreign direct investment (DR).

GDP refers to left side Y-axis; EX, IM, CR and DR refer to right side Y-axis.

\section{LITERATURE REVIEW}

Countries can sustain in high development of the national economy through the open economy. Economic integration includes export, import, inward FDI and outward FDI. Neoclassical model views that technological progress can be transferred from one country to another country via export, import, and FDI to sustain the economy in the long run. Hence, this study uses export, import and FDI to determine economic growth.

A country exports to another country because the productive resources are more efficient outside of its country in order to compete in the international market (Kristjanpoller \& Oslon, 2014). The more the country exports, the higher the growth rate of output. This is because the expansion in exports will cause a country to become specialised in production. When a country adopts advanced technology, employees gain more skills and capacities which in turn increases the productivity level (Maswana, 2014). However, different countries would have different impacts of export on economic growth due to varying trade policies (Krasniqi \& Topxhiu, 2017). Iqbal, Turray and Sami (2017) conducted research to study the impact of bilateral trade between India and the United State (US) on India's economic growth from the year 1985 to 2015. By using the regression model, the results show that export has a statistically significant impact on gross domestic product (GDP).

Other than that, when countries bring in capital and intermediate goods into domestic production, they gain sophisticated technology to increase production, export activities and in turn economic growth (Shahbaz \& Rahman, 2012). Maswana (2014) states that through imports, a country can learn from the accessed technical knowledge and promote technological transfer easily to improve 
the local productivity growth, but Makun (2018) mentions that learning by doing process in the import sector grows slower than in export sectors. This will cause the imported country to lose competitive advantages across foreign competitors. In addition, a country who is over-relying on imports might unable to cover the cost owing to the lack of domestic production and this, in turn, harm the local economic growth. Iqbal et al. (2017) also conducted research to study the impact of imports from US on India's economic growth. Using data from the year 1985 to 2015, the regression model shows a significant impact of imports on India's GDP growth.

Besides that, inward FDI acts as a channel to transfer physical capital and human capital to the receiving country to increase the economic growth rate (Alvarado, Iniguez \& Ponce, 2017). By setting foot in a foreign country, multinational firms can train local worker and managers to access the international market easily (Blomström \& Kokko, 1998). Host country's firms are also given resources and capabilities needed for internalisation from foreign owners such as new products, technology, managerial skills and marketing skills (Davidkov \& Yordanova, 2015). It is inevitable that foreign firms become a monopoly in certain sectors and lead to price distortion and misallocation of resources. Ultimately, the recipient country faces stagnant growth because the economy is controlled by foreigners (Khatun \& Ahamad, 2015). The study done by Testas (2014) focuses on how inward FDI of the European Union (EU) in Tunisia will affect Tunisia's economic growth. His study applied a quantitative approach in the theory of international investment in which real GDP depends on inward FDI. The results from the analysis concluded that Tunisia-EU investment liberalisation has led to the rapid growth rate in Tunisia because there is a significant relationship between inward FDI and economic growth.

Last but not least, outward FDI can be characterised by the investment of private or public individual firms in foreign countries to expand beyond domestic borders via green-field, alliance or acquisition (Garcia, Jin \& Salomon, 2012). The purpose for a country to do so might because they want to learn from the overseas investment and capture value for themselves and other firms in home countries (Lim \& Teo, 2019). The country might also motivate to exploit the opportunity granted by foreign markets (Dunning, 1993). However, the positive or negative impact of outward FDI on domestic economic growth depends on its role in the domestic market. The outward FDI can reduce economic growth if domestic firms keep on moving out from home country which in turn leads to an increase in the unemployment rate (Rodrik, 2016). Since outward FDI involves high risks and high uncertainties because of the long time lag between the investment and revenues generated by investors, it is important for investors to carefully examine the host country to ensure credible and friendly host country's commitment to investment policy, otherwise, outward FDI will harm the home country's economic growth (Jung \& Rich, 2015). Herzer (2008) discussed the relationship between outward FDI and economic growth in 14 industrialised countries over the period 1971 to 2005 using panel cointegration technique. The findings reveal that outward FDI has significant long-run effects on domestic outputs.

From the summary of the literature review, exports, imports, inward FDI and outward FDI are the determinants of economic growth and they affect economic growth significantly. Therefore, in this study, the highlighted contributions are the examinations of the relationship between Malaysia exports to, imports from, inward FDI by, outward FDI in Singapore and Malaysia's economic growth. 


\section{METHODOLOGY}

This study employs quarterly data from year 2008 to year 2016 from the Bloomberg database. The period starts from year 2008 because the global crisis has prompted the government of Malaysia to publish quarterly data related to trade which is an important factor will affect the growth of an economy. The dependent variable is Malaysia's economic growth which is proxied by the growth of Gross Domestic Products (GDP). The independent variables are Malaysia exports to Singapore (EX), Malaysia imports from Singapore (IM), Malaysia inward foreign direct investment by Singapore (CR), and Malaysia outward foreign direct investment in Singapore (DB). All the data are employed in the value of Malaysian Ringgit in million, except for the growth of GDP in percentage.

To establish the procedure, the assessment of the causal relationship between the variables is performed in stages. First, unit root test is executed to test for the existence of unit roots to identify whether the variables are stationary or non-stationary (Chan, Puah \& Wong, 2019; Azlina, Law \& Mustapha, 2014). This study employs Augmented Dickey Fuller (ADF) and Phillips Perron (PP) unit root tests. ADF test has restricted the power to reject a unit root, so the PP test is to complement the ADF test to correct for serial correlation in unit root testing. Second, the con-integration test by Johansen and Jesulius (1990) is conducted to examine the presence of a long-run relationship among all variables within a multiple framework. This technique is a vector autoregressive (VAR)based test of restrictions enacted by co-integration on the unrestricted VAR. Third, short-run Granger causality using a vector error correction model (VECM) framework is performed. The short-run investigation should include the error correction term (ECT) to incorporate the adjustment for the deviation from its long-run equilibrium. The VECM model used for examining the Granger causality can be characterised by:

$$
X_{t}=\left(\begin{array}{c}
\Delta \ln G D P \\
\Delta \ln E X \\
\Delta \ln I M \\
\Delta \ln C R \\
\Delta \ln D R
\end{array}\right)=\left(\begin{array}{c}
\beta_{1} \\
\beta_{2} \\
\beta_{3} \\
\beta_{4} \\
\beta_{5}
\end{array}\right)+\left(\begin{array}{cccc}
\alpha_{11}(L) & \alpha_{12}(L) & \ldots & \alpha_{15}(L) \\
\alpha_{21}(L) & \alpha_{22}(L) & \ldots & \alpha_{25}(L) \\
\vdots & & & \\
\alpha_{51}(L) & \alpha_{52}(L) & \ldots & \alpha_{55}(L)
\end{array}\right)+\left(\begin{array}{c}
\Delta \ln G D P \\
\Delta \ln E X \\
\Delta \ln I M \\
\Delta \ln C R \\
\Delta \ln D R
\end{array}\right)+\left(\begin{array}{c}
\gamma_{1} Z_{1, t-1} \\
\gamma_{2} Z_{2, t-1} \\
\vdots \\
\gamma_{5} Z_{5, t-1}
\end{array}\right)+\left(\begin{array}{cccc}
\Phi(L) & 0 & \ldots & 0 \\
0 & \Phi(L) & \ldots & 0 \\
\vdots & & & \\
0 & \alpha_{52}(L) & 0 & \Phi(L)
\end{array}\right)\left(\begin{array}{c}
\varepsilon_{1, t} \\
\varepsilon_{2, t} \\
\varepsilon_{3, t} \\
\varepsilon_{4, t} \\
\varepsilon_{5, t}
\end{array}\right)
$$

where $X_{t}$ is a $(5 \times 1)$ vector of the variables in the system, $\beta$ 's represent a vector of constant terms, $\alpha$ 's are estimable parameters, difference operators is represented by $\Delta, \mathrm{L}$ is a lag operators, $\alpha(\mathrm{L})$ and $\Phi(\mathrm{L})$ are finite polynomials in the lag operators, $Z_{t-1}$ 's are error correction terms where its coefficients test speed of adjustment, and $\varepsilon_{t}{ }^{\prime} s$ are disturbances.

Based on the variables suggested by Iqbal et al. (2017), Rahman and Shahbaz (2013), and Herzer (2008), the estimated equation after the natural logarithm transformation based on Vector Error Correction Model (VECM) is as below:

$\Delta \ln G D P_{t}=\beta_{0}+\sum_{k=1}^{n} \Delta \ln G D P_{t-1}+\sum_{k=1}^{n} \Delta \ln E X_{t-1}+\sum_{k=1}^{n} \Delta \ln I M_{t-1}+\sum_{k=1}^{n} \Delta \ln C R_{t-1}+$ $\sum_{k=1}^{n} \Delta \ln D B_{t-1}+\beta_{1} \ln E X_{t-1}+\beta_{2} \ln I M_{t-1}+\beta_{3} \ln C R_{t-1}+\beta_{4} \ln D B_{t-1}+\varepsilon_{t}$

VECM is applied to analyse the effect of independent variables on the dependent variable and the coefficient of each independent variable shows how many percent changes of the dependent 
variable when a unit change of each independent variable. The inclusion of significant and negative coefficient of error correction term (ECT) in VECM helps to correct any short-run fluctuations in the long-run equilibrium relationship among variables (Norazman, Khalid, \& Ghani, 2018).

\section{RESULTS AND DISCUSSIONS}

Table 1 shows the Augmented Dickey Fuller (ADF) and Philip Pherron (PP) tests indicate that all the variables are integrated at the first difference. The null of unit root is being rejected at $5 \%$ or $1 \%$ significance level for all variables. Therefore, all the four variables appear to be integrated of order one, I (1). It also explains that the model has long-run equilibrium relationship among the variables. This fulfils the requirement for VECM (Chan, Puah \& Wong, 2019).

Table 1: Results of unit root tests

\begin{tabular}{|c|c|c|c|c|}
\hline \multirow[b]{3}{*}{ Variable } & \multicolumn{2}{|c|}{ Augmented Dickey Fuller (ADF) } & \multicolumn{2}{|c|}{ Phillips Perron (PP) } \\
\hline & \multicolumn{4}{|c|}{ Level } \\
\hline & $\begin{array}{c}\text { Constant } \\
\text { Without Trend }\end{array}$ & $\begin{array}{c}\text { Constant With } \\
\text { Trend }\end{array}$ & $\begin{array}{c}\text { Constant Without } \\
\text { Trend }\end{array}$ & $\begin{array}{c}\text { Constant With } \\
\text { Trend }\end{array}$ \\
\hline $\operatorname{lnGDP}$ & -2.3815 & -2.5178 & -2.7821 & -2.8735 \\
\hline $\operatorname{lnEX}$ & 0.7807 & $-5.6514 * * *$ & -1.6420 & -3.1867 \\
\hline $\operatorname{lnIM}$ & -1.9495 & -0.7739 & -1.9102 & -2.6119 \\
\hline $\operatorname{lnCR}$ & $-3.8308 * * *$ & $-6.0312 * * *$ & $-3.7945 * * *$ & $-12.4989 * * *$ \\
\hline \multirow[t]{2}{*}{$\ln \mathrm{DB}$} & $-5.6933 * * *$ & $-4.7612 * * *$ & $-5.7340 * * *$ & $-6.8672 * * *$ \\
\hline & \multicolumn{4}{|c|}{ First Difference } \\
\hline $\operatorname{lnGDP}$ & $-8.4967 * * *$ & $-9.29 * * *$ & $-3.1836 * *$ & $-3.0759 * *$ \\
\hline $\operatorname{lnEX}$ & $-5.7890 * * *$ & $-5.6779 * * *$ & $-6.8297 * * *$ & $-7.9510 * * *$ \\
\hline $\ln I M$ & $-1.4218 * *$ & $-5.8088 * * *$ & $-6.0363 * * *$ & $-5.9234 * * *$ \\
\hline $\operatorname{lnCR}$ & $-6.3600 * * *$ & $-6.1351 * * *$ & $-18.3278 * * *$ & $-18.0664 * * *$ \\
\hline $\ln \mathrm{DB}$ & $-7.8530 * * *$ & $-4.2074 * *$ & $-21.5733 * * *$ & $-21.0895 * * *$ \\
\hline
\end{tabular}

Note: $* * *$ and $* *$ denotes significant at $1 \%$, and $5 \%$ significance level, respectively

Table 2 shows the result of residual diagnostic. It is shown that the p-value of normality test, breusch-godfrey serial correlation LM test, and autoregressive conditional heteroscedasticity $(\mathrm{ARCH})$ test are more than 5\% significant level. The results conclude that the null hypotheses are not rejected (Norazman et al., 2018). Variance inflation factor (VIF) is used to measure the level of multicollinearity between the explanatory variables. The VIF concludes that there is no serious multicollinearity among the explanatory variables.

Table 2: Results on The Residual Diagnostic

\begin{tabular}{ll}
\hline \hline Residual Diagnostic & Probability \\
\hline Normality Test & 0.4651 \\
Breusch-Godfrey Serial Correlation LM Test & 0.5361 \\
Heterosckedasticity Test: ARCH & 0.2158 \\
\hline \hline
\end{tabular}


Besides that, Figure 2 and 3 represent the results of the cumulative sum (CUSUM) and cumulative sum of square (CUSUMSQ) test on the recursive residuals. The results reveal that the statistics of CUSUM and CUSUMSQ test are within the critical bound of 0.05 significant level. Hence, the residuals are said to be structural stable in the equation (Norazman et al., 2018).

Figure 2: Plot of Cumulative Sum (CUSUM) of Recursive Residuals

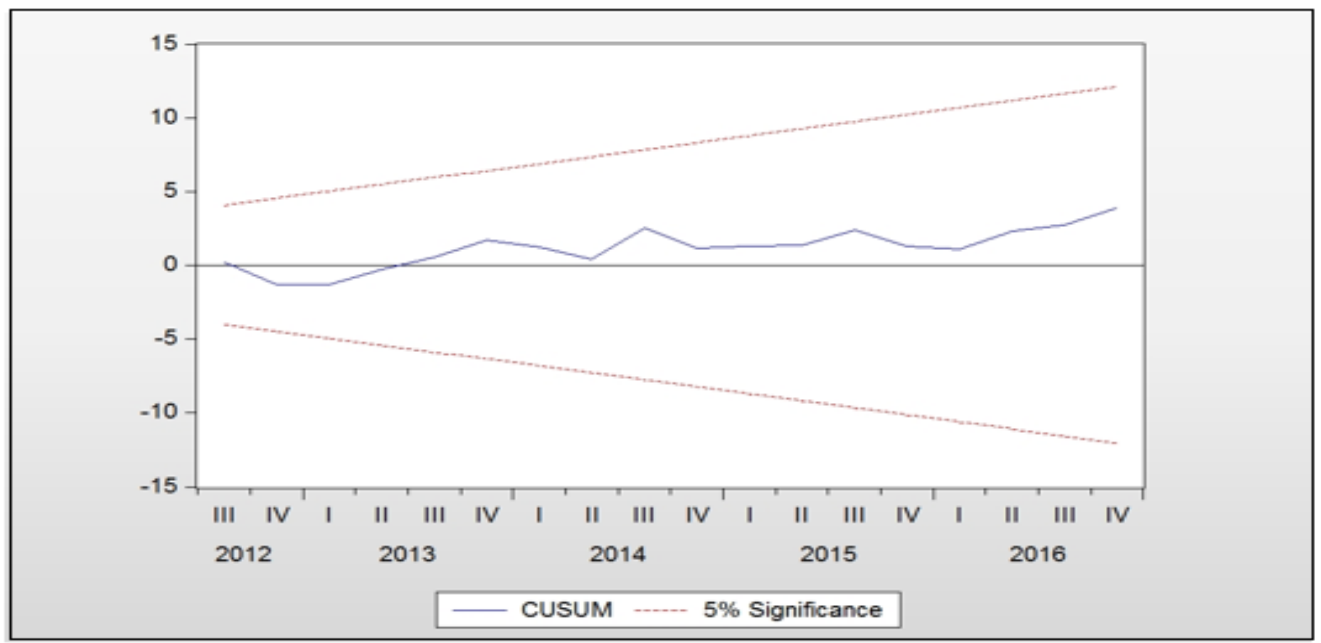

Figure 3: Plot of Cumulative Sum of Squares (CUSUMSQ) of Recursive Residuals

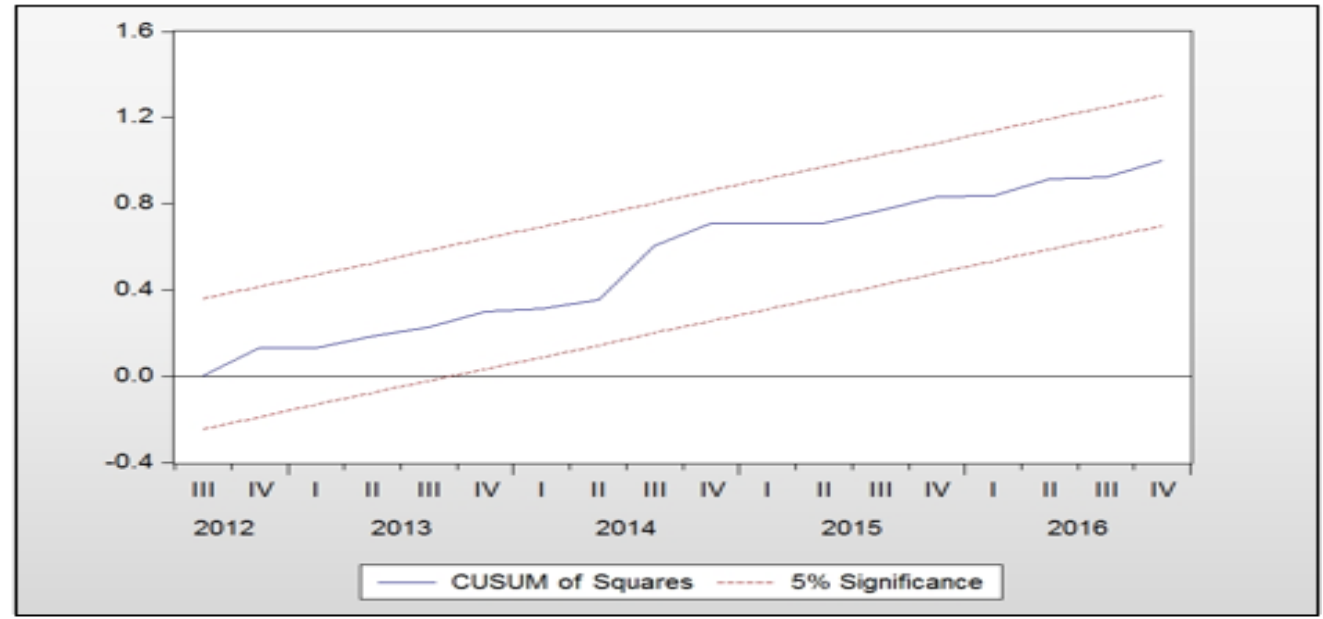

In addition, the results of cointegration tests in Table 3 shows that there is a long-run relationship between independent and dependent variables from the specified model. 
Table 3: Results of Cointegration Tests

\begin{tabular}{ccccc}
\hline \hline $\boldsymbol{H}_{\mathbf{0}}$ & Trace Statistics & $\mathbf{0 . 0 5}$ Critical Value & Max-Eigen Stats & 0.05 Critical Value \\
\hline None & 163.7124 & $69.8189^{* *}$ & 67.1123 & $33.8769^{* *}$ \\
At most 1 & 96.6001 & $47.8561^{* *}$ & 55.7852 & $27.5843^{* *}$ \\
At most 2 & 40.8149 & $29.7971^{* *}$ & 25.0697 & $21.1316^{* *}$ \\
At most 3 & 15.7452 & $15.4947^{* *}$ & 14.1518 & 14.2646 \\
At most 4 & 1.5934 & 3.8415 & 1.5934 & 3.8415 \\
\hline \hline
\end{tabular}

Following the results above, the VECM is specified as follows:

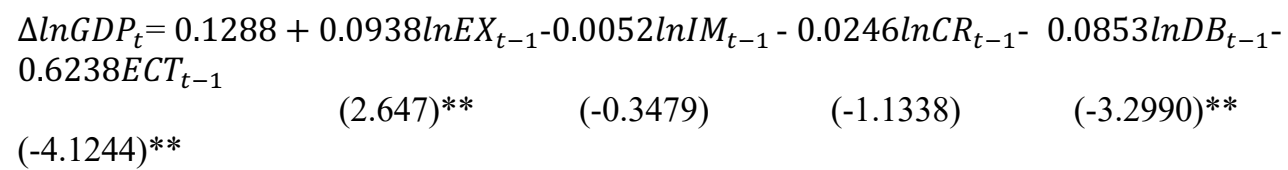

The long-run equation of InGDP reveals that Malaysia exports to Singapore have a positive and significant relationship with Malaysia's economic growth. When Malaysia has a $1 \%$ increase in export production to Singapore, it will stimulate economic growth by $0.0938 \%$. This is because Singapore is the largest export partner of Malaysia, the statistics by Trading Economics (2019) shows that $15 \%$ of Malaysian total export in 2017 is to Singapore. Although China and the United States are among the largest economy in the world, but the export of Malaysia to these countries is $13.1 \%$ and $9.5 \%$ respectively (Wong, 2019). This confirms the position of Malaysia as an exportoriented country which highly dependent on export activities to compete in the international market. Interestingly, Wang and Le (2018) also report that Malaysia and Singapore are among the efficient international market selection for conducting exports. Therefore, Malaysia should take benefit from this comparative advantage, maintain a good relationship with Singapore and specialize its exportation of products to Singapore. This finding is consistent with the recommendation by Karimi and Malekshahian (2018) that the ASEAN countries should improve the region into a stable, production base, highly competitive, single market, equitable economic development and completely integrated into the global economy.

Besides that, Malaysia imports from Singapore does not have any significant relationship with Malaysia's economic growth probably due to the economic slowdown and depreciation in Malaysian Ringgit during the period of 2008 and 2016, which in turn slow down the domestic consumption and therefore form negative relationship between Malaysia import from Singapore and Malaysia's economic growth. This discovery confirms the finding by Aftab and Rehman (2017), exchange rate volatility causes import demand of Malaysia is unstable. Nevertheless, it is also suggested there is an existence of the elastic nature of Malaysian import demand for Singaporean goods in specific industries. When a currency depreciates, import demand declines. On the other hand, when a currency appreciates, imports demand accelerates. This could be the reason that causes our finding shows the insignificant overall impact of imports from Singapore to the economic growth of Malaysia.

Other than that, when Malaysia inward FDI by Singapore 1\%, Malaysia's economic growth will decrease by $0.0246 \%$. The negative relationship might be due to the presence of growth-limiting effects of foreign direct investment such as the shortage of skilled workforce in Malaysia. However, 
the relationship between Malaysia inward FDI by Singapore and Malaysia's GDP is not significant as the contribution of foreign direct investment to Malaysia's GDP growth merely occupies little portion. The insignificant result could be probably due to this study employs the overall industry inward foreign direct investment. Abdul Hadi, Zafar, Iqbal, Zafar, and Iqbal Hussain (2018) highlight that analysing the impact of inward foreign direct investment based on sectoral level because FDI is not a single phenomenon and that each sector must be treated on its terms to appeal FDI into the country.

Lastly, Malaysia's outward FDI in Singapore has a significant relationship with Malaysia's economic growth as a result of economic liberalisation as well as the globalisation of production pattern. Additionally, there is a negative impact of Malaysia's outward FDI in Singapore on Malaysia's economic growth. This might because the majority investment in Singapore's output does not allow Malaysia to bring back any proprietary technology or human capital that can enhance its GDP growth. Wang, Lin and Yang (2017) describe that a country with a scarcity of financial resources and an imperfect financial market, outward FDI may increase domestic interest rates by transferring funds out of the home country, minimising the borrowing intentions of domestic firms. Hence, outward FDI may weaken investment in the home country, boosting domestic firms to internally finance their overseas investments because of high-interest rates. This implies that Malaysia uses domestic finance for the FDI activities in Singapore, to support the production in Singapore, but unable to stimulate the economic growth of Malaysia due to the difficulty to transfer back the intellectual property is produced in Singapore to Malaysia.

Furthermore, Figure 4 presents ten quarters responses of the dependent variable towards the shocks stemming from other independent variables under the vector autoregressive (VAR) system. The results show that one standard deviation innovative shock in exports will increase economic growth within one year, and it increases significantly over the third quarter as the lower confidence interval (the two standard deviation band denoted by the dotted line) crosses the zero line. Economic growth also reacts positively and significantly to structural innovations in imports in the sixth quarter. Albeit one standard deviation innovative shock in inward foreign direct investment will increase economic growth in a year, but it is insignificant. Imports seem to have the greatest impact on economic growth in the short run because the positive and significant impact of imports on economic growth has the longest period of time. The response of economic growth to a shock in the outward foreign direct investment is negative and not significant in the short run as the lower two standard deviations are below the zero line for the entire time horizon. It is reasonable as Malaysian government is spending money out of the country and the investment has not yet generated income for the economic growth in a short period of time. 
Figure 4: Results of Impulse Response Function

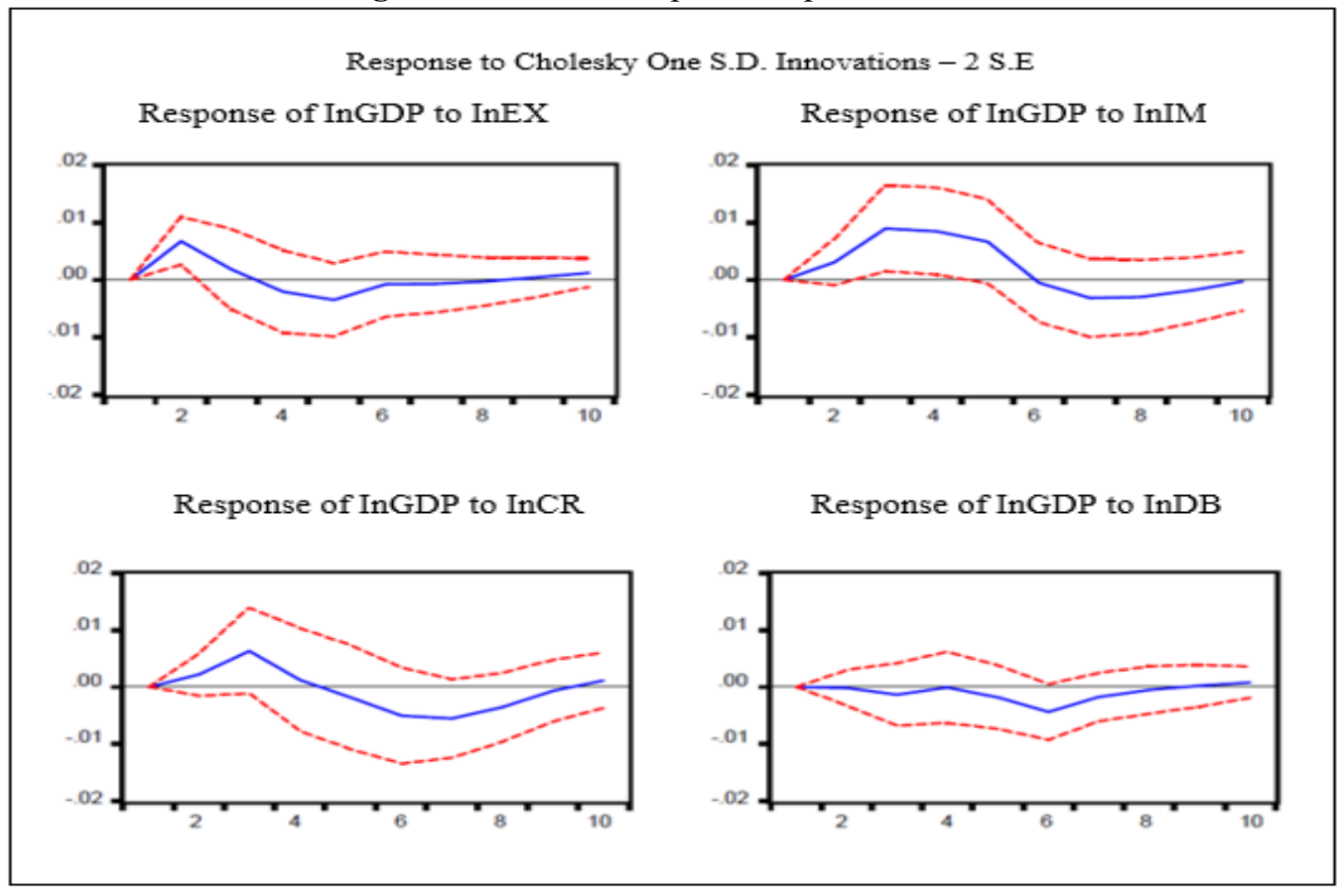

The results of variance decomposition in Table 4 suggests that economic growth in Malaysia is very sensitive to its own shock and other variables. $100 \%$ of the variation in economic growth is explained by itself in the first quarter and that this slowly drops to about $42 \%$ in the tenth period. This implies that economic growth is the endogenous variable. Exports, imports, inward foreign direct investment and outward foreign direct investment explain economic growth by 8.9 percent, $29.5 \%, 15.7 \%$ and $3.8 \%$ respectively in the tenth period. This shows that imports are the most important determinant of economic growth in Malaysia in the short run. While economic growth is not very responsive to exports and the response of economic growth towards the outward foreign direct investment is the least.

Table 4: Results of Variance Decomposition

\begin{tabular}{cccccc}
\hline \hline Period & InGDP & $\operatorname{lnEX}$ & $\operatorname{lnIM}$ & $\operatorname{lnCR}$ & $\operatorname{lnDB}$ \\
\hline 1 & 100.00 & 0.00 & 0.00 & 0.00 & 0.00 \\
2 & 81.25 & 14.26 & 3.03 & 1.44 & 0.01 \\
3 & 62.64 & 9.82 & 18.11 & 9.04 & 0.39 \\
4 & 54.88 & 9.14 & 27.69 & 7.96 & 0.33 \\
5 & 49.53 & 10.17 & 31.78 & 7.70 & 0.83 \\
6 & 46.19 & 9.58 & 29.67 & 10.95 & 3.61 \\
7 & 43.50 & 9.03 & 29.17 & 14.48 & 3.82 \\
8 & 42.42 & 8.75 & 29.40 & 15.69 & 3.74 \\
9 & 42.2 & 8.72 & 29.69 & 15.67 & 3.72 \\
10 & 42.10 & 8.85 & 29.53 & 15.74 & 3.78 \\
\hline \hline
\end{tabular}




\section{CONCLUSION}

This study discusses the existence of the relationship between Malaysia exports to Singapore, Malaysia imports from Singapore, Malaysia inward FDI by Singapore, Malaysia outward FDI in Singapore and Malaysia's economic growth. The results show that only Malaysia exports to Singapore has a significant and positive relationship with Malaysia's economic growth. The results show that Malaysia is well-known as an export-oriented country. Hence, it is concluded that Malaysia's economic growth could be enhanced by exporting to Singapore. In other word, Singapore and Malaysia have a complementary relationship on exporting activities only. Therefore, Malaysian government policymakers should encourage domestic firms to make more exports to Singapore by implementing a various campaign and providing incentives.

Although Malaysia outward FDI in Singapore is significant to Malaysia's economic growth, there is a negative relationship. The majority of investment in service sectors seems like it did not provide any backward linkage, hence, Malaysian government policymakers and local firms can focus on investing in value-added manufacturing sectors. On the contrary, Malaysia imports from Singapore and Malaysia inward FDI by Singapore do not help to increase Malaysia's economic growth because both imports and inward FDI are showed to be not significant and negative to Malaysia's economic growth.

The implications of this study suggest that domestic small and medium enterprises (SMEs) can focus on importing proprietary technology and human talent to produce quality products for future export purposes in order to stay competitive against international competitors. The transfer of skills and knowledge from foreigners to locals can occur through imports. Moreover, the government of Malaysia could implement a various campaign and provide incentives to encourage local firms to make more export to Singapore. This is because Singapore is a good exporting destination due to the large demand for Singaporean and exposure to other foreign markets. When there is an expansion in exporting, Malaysia can specialise in the production and achieve economies of scale to increase output productivity. In addition, Malaysian government and domestic SMEs could encourage foreign direct investment in other sectors that allow Malaysia to bring in proprietary technology and human capital from Singapore in order to enhance Malaysia's economic growth.

Furthermore, the results show the negative impact of foreign direct investment by Singapore on Malaysia's economic growth. There are some reasons that prohibit the growth effect of inward foreign direct investment by Singapore. One of the reasons is the shortage of skilled labour despite the Singaporean firms have a physical presence in Malaysia, Hence, the government of Malaysia could address this issue promptly.

\section{REFERENCES}

Abidin, I. S. Z. (2017, August 30). Good GDP growth: Economy is in stronger position. New Straits Times. Retrieved from https://www.nst.com.my/opinion/columnists/2017/08/ 274447/good-gdp-growth-economy-stronger-position 
Abdul Hadi, A. R., Zafar, S., Iqbal, T., Zafar, Z., \& Iqbal Hussain, H. (2018). Analyzing sectorial level determinants of inward foreign direct investment (FDI) in ASEAN. Polish Journal of Management Studies, 17(2), 7-17.

Aftab, M., \& Rehman, I. U. (2017). Exchange rate risk and the bilateral trade between Malaysia and Singapore. Studies in Economics and Finance, 34(3), 407-426.

Alvarado, R., Iniguez, M., \& Ponce, P. (2017). Foreign direct investment and economic growth in Latin America. Economic Analysis and Policy, 56, 176-187.

Azlina, A. A., Law, S. H., \& Mustapha, N. H. N. (2014). Dynamic linkages among transport energy consumption, income and CO2 emission in Malaysia. Energy Policy, 73, 598-606.

Blomström, M., \& Kokko, A. (1998). Multinational corporations and spillovers. Journal of Economic Surveys, 12(3), 247-277

Davidkov, T., \& Yordanova, D. (2015). Enhancing SME internationalization in a transition economy: The role of internal factors. International Journal of Latest Trends in Finance \& Economic Sciences, 5(3), 945-956.

Chan, T. H., Puah, C. H., \& Wong, S. L. (2019). Exchange rates, monetary aggregates, industrial production and shock adjustments in Malaysia after the capital control. International Journal of Business \& Society, 20(1), 95-110.

Dunning, J. H. (1993). Multinational Enterprises and the Global Economy. Addison Wesley Publishing Co., Harlow, Essex.

Economic Planning Unit (EPU). (2015). Anchoring growth on people (11th ed.). Putrajaya: Author.

Garcia, F., Jin, B., \& Salomon, R. (2012). Does inward foreign direct investment improve the innovative performance of local firms? Research policy, 42(1), 231-244.

Hays, J. (2015). Trade and foreign direct investment in Singapore. Retrieved March 20, 2018, from http://factsanddetails.com/southeast-asia/Singapore/sub5_7c/entry-3791.html

Herzer, D. (2008). The long-run relationship between outward FDI and $\bar{d}$ omestic output: Evidence from panel data. Economics Letters, 100(1), 146-149.

Iqbal, B. A., Turray, A. M., \& Sami, S. (2017). Impact of Indo-US trade on India's economic growth: An emprical analysis. Transnational Corporations Review, 9(1), 8-15.

Jung, H. J., \& Rich, T. S. (2015). Why invest in North Korea? Chinese foreign direct investment in North Korea and its implications. The Pacific Review, 29(3), 307-330.

Khatun, F., \& Ahamad, M. (2015). Foreign direct investment in the energy and power sector in Bangladesh: Implications for economic growth. Renewable and Sustainable Energy Reviews, 52, 1369-1377.

Krasniqi, F. X., \& Topxhiu, R. M. (2017). Export and economic growth in the West Balkan Countries. The Romanian Economic Journal, 20(65), 88-104.

Kok, C. (2013, March 16). Warming ties between Malaysia and Singapore. The Star. Retrieved https:/www.thestar.com.my/business/business-news/2013/03/16/warming-ties-betweenmalaysia-and-singapore/

Kristjanpoller, R., \& Olson, J. E. (2014). Economic growth in Latin American Countries: Is it based on export-led or import-led growth? Emerging Markets Finance and Trade, 50(S1), 6-20.

Lee, M. (2017, September 27). Singapore slips a notch to 3rd most competitive economy. The Straits Times. Retrieved http://www.straitstimes.com/business/singapore-slips-a-notchto-3rd-most-competitive-economy

Lim, G., \& Teo, J. K. (2019). Climbing the economic ladder: The role of outward foreign direct investment. Journal of Asian Public Policy, 12(3), 312-329. 
Lum, K. K. (2018, January 15). Khazanah and Temasek deliver Marina One and DUO in Singapore. Edge Prop. Retrieved from https://www.edgeprop.my/content/1270073/ khazanah-and-temasek-deliver-marina-one-and-duo-singapore

Makun, K. K. (2018). Imports, remittances, direct foreign investment and economic growth in Republic of the Fiji Islands: An empirical analysis using ARDL approach. Kasetsart Journal of Social Sciences, 39(3), 439-447.

Maswana, J. C. (2014). Can China trigger economic growth in Africa? The Chinese Economy, 42(2), 91-105.

Ministry of International Trade and Industry (MITI). (2017). The ASEAN day opening ceremony 9 August 2017, MITI Tower, Kuala Lumpur. Malaysia.

Norazman, U. Z., Khalid, H., \& Ghani, G. M. (2018). Food inflation: A study on key determinants and price transmission processes for Malaysia. International Journal of Business and Society, 19(1), 117-138.

Rodrik, D. (2016). Premature deindustrialization. Journal of Economic Growth, 21(1), 1-33.

Shahbaz, M., \& Rahman, M. M. (2012). The dynamic of financial development, imports, foreign direct investment and economic growth: Cointegration and causality analysis in Pakistan. Global Business Review, 13(2), 201-219

Trading Economics (2019). Malaysia exports by country. The Star Online. Retrieved from https://www.thestar.com.my/business/business-news/2013/03/16/warming-ties-betweenmalaysia-and-singapore/

Testas, A. (2014). The contribution of EU investment to Tunisia's economic development. The Journal of North African Studies, 5(2), 9-24.

Wang, C. N., \& Le, A. P. (2018). Application in international market selection for the export of Goods: A case study in Vietnam. Sustainability, 10(12), 4621.

Wang, L, T, Lin, H. P., \& Yang, C. L. (2017). Causality on outward foreign direct investment and domestic investment in newly industrialized Asian countries. Economic Computation \& Economic Cybernetics Studies \& Research, 51(2), 268-280.

Wong, H. T. (2019). Volatility and bilateral exports in Malaysia. International Journal of Business \& Society, 20(2), 605-626. 